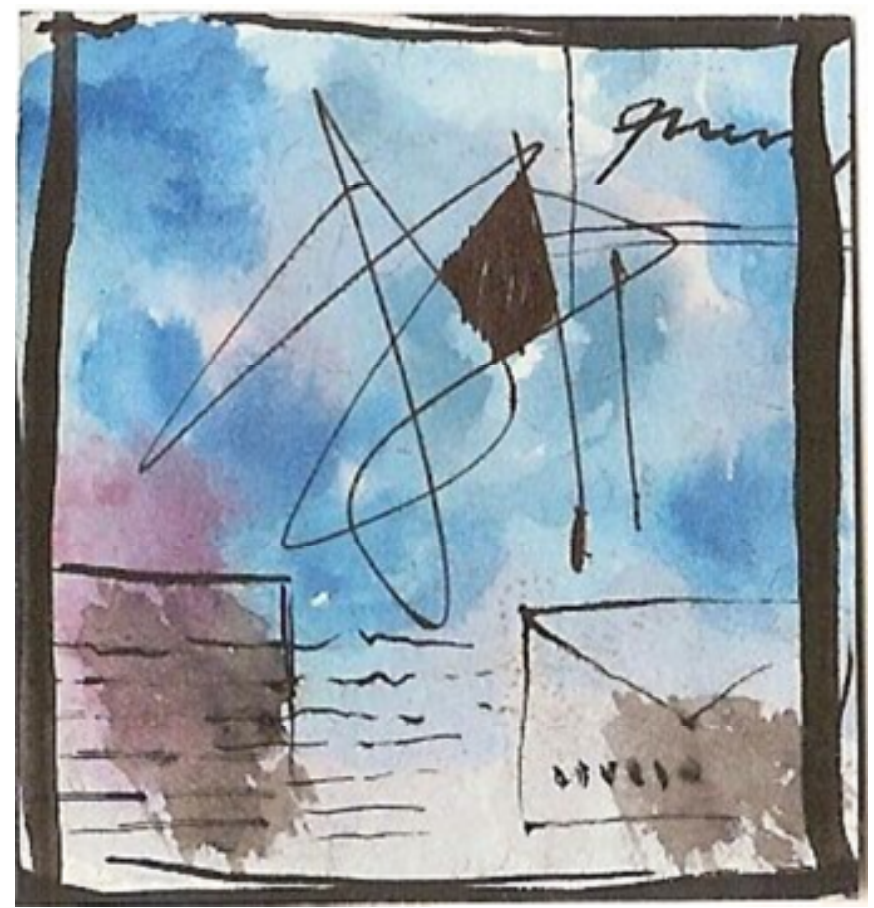

Ilustração Douglas Veloso

\title{
Correntes de Humboldt: redes de linguagem
}

\section{Maria Antonieta Pereira}

Maria Antonieta Pereira é professora de Teoria da Literatura e Literatura Comparada na Faculdade de Letras/UFMG. Pós-doutora pela Universidad de Buenos Aires. Autora de vários livros e artigos sobre telas, textos e educação. Pesquisa atual: Tecnologias intelectuais da leitura. Coordenadora do Programa de Ensino, Pesquisa e Extensão A tela e o texto.

\section{D’ANGELO, Biagio. Humboldt. Lima: Editorial Estruendomudo,} 2006.

Humboldt é uma obra realmente transnacional. Escrita por um siciliano e professor de universidade peruana, a coletânea de poemas é, em grande parte, uma abordagem do Brasil nas línguas italiana e espanhola. Além disso, o título da obra é uma homenagem a dois famosos alemães: aquele que foi um naturalista totalmente transdisciplinar e aquele que identificou a linguagem humana como um sistema governado por 
regras, o que permite a criação de infinitas frases por meio de um número finito de palavras(1).

Parece ser esse o caminho desenvolvido pelos poemas de Humboldt - vertendo imagens brasileiras para o italiano e, logo a seguir, para o espanhol, a obra busca expandir-se multiplicando, pela tradução, o universo restrito das palavras de cada língua. Cruzando os fios invisíveis dessas cadeias de palavras, a inquieta poesia de D'Angelo explode de paixão pela vida e por paisagens brasileiras, contempladas por um olhar estrangeiro que não se limita, contudo, à mera percepção do turista. Num dos primeiros textos da obra, a imagem de Afrodite paira sobre "cantos sussurrados" e "sons préhistóricos" que convocam os amantes a morrerem de silêncio, ao sul de Niterói ou em plena Guanabara. Em "Jardim Botânico", um olhar quase oriental (Sherazade habituada à secura do deserto) contempla em êxtase a verdura das mangueiras e dos mil amores extraviados. Alguns versos do Carinhoso de Pixinguinha funcionam como epígrafe do texto "Ipanema", revelando um amor esquivo que se desdobra em mistérios e se acaricia em saudades. Ao se afirmar, noturno e belo, esse amor é também um conflito entre as certezas do amante ("eu sei que tu") e as incertezas do verbo no futuro do pretérito ("não fugirias mais de mim").

Outra epígrafe, dessa vez de Machado de Assis, anuncia o poema "Memórias póstumas" com sua dor filosoficamente destilada. Os conflitos entre com-paixão, vaidade, delírio, cinzas e sombras levam o texto a falar diretamente a seus supostos cinco leitores, anunciando-lhes a pseudo morte de Brás Cubas que, de fato, estaria prisioneiro do relato e do tempo. Em "Serra gaúcha", a poesia estabelece uma comunhão entre homens e natureza: sol, água, abismos, folhas verdes e as palavras portuguesas mato, serra, joão-de-barro vibrando em itálico no corpo do texto são o prenúncio de uma felicidade aflita e luminosa. Maria Mutema, personagem de Guimarães Rosa, figura na poesia de "Sertão" como uma jagunça que promete beijos na Praça da Liberdade (Belo Horizonte). No espaço imaginado pelo texto, dentre jacarés e sabiás, surge um Deus sertanejo que se ilumina no fogaréu misericordioso dos ipês de Minas.

Além das referências ao Brasil, que nos salta aos olhos por razões óbvias, a obra se destaca pela perspectiva navegante do eu poético. No poema "Humboldt", encontram-se os elementos marítimos da viagem: mapas, galeões, cabos, Ulisses e Colombos deslocam-se até a corrente fria que visita as costas peruanas e foi descoberta pelo naturalista. Outros viajantes textuais, como Melville, Gadda e Bruce Chatwin, contribuem para mesclar as aventuras culturais de norte-americanos, italianos, brasileiros e agudás. 
Outro fato digno de nota em Humboldt são as cartas endereçadas a Gustav Mahler, Marina Tsvietáieva e Gertrude Stein, dentre outros. Os tons de despedida e distância inaceitável mostram os meios pelos quais os versos contemporâneos, apropriando-se de textos verbais e musicais, vão construindo interlocutores no passado pela disseminação, nas leituras de hoje, dos desejos, afetos e problemas desses precursores.

Como a corrente de Humboldt que, rica em plânctons e peixes, também forja as brumas limenhas, a poesia de Biagio D'Angelo corre livre pelos mares da linguagem, unindo águas do Norte e do Sul, mas mantendo-se em diferença. Rio dentro do oceano, Humboldt é um experimento de linguagem típico de certa pósmodernidade. Construindo-se enquanto picada aquosa que logo se desfaz, garante sua pervivência pela capacidade de continuar em movimento, fluindo eternamente no espaço tenso da travessia. Rio sem margens, essa coletânea de poemas transborda o espaço das literaturas nacionais e, por isso mesmo, contribui imensamente para formar os leitores típicos do século XXI.

\section{Notas}

(1) Friedrich Heinrich Alexander, Barão von Humboldt, era especialista em etnografia, antropologia, física, geologia, mineralogia, botânica, vulcanologia e humanismo, tendo lançado as bases de novas ciências como Geologia, Climatologia e Oceanografia. Seu irmão Friedrich Wilhelm Christian Karl Ferdinand foi funcionário do governo, diplomata, filósofo, fundador da Universidade de Berlim, amigo de Schiller e Goethe. Sendo lingüista, introduziu o conhecimento da língua basca no meio intelectual europeu. Suas teorias forneceram uma das bases da gramática transformacional de Chomsky. (cf. wikipedia - acessado em 05/12/06).

\section{Bibliografia}

D’ANGELO, Biagio. Humboldt. Lima: Editorial Estruendomudo, 2006. 